УДК 338.1:338.486.021.8 (477)

\title{
REFORMING OF THE TOURISM INDUSTRY IN UKRAINE
}

\author{
Iryna Zhuk \\ Ivan Franko National University of Lviv, \\ 1, Universytetska Srt., Lviv, Ukraine, 79000, tel.: (032) 239-46-03, \\ E-mail: zhukiryna0312@gmail.com
}

"The state that has no funds to ensure the reforms, doesn't have funds to exist as before"

Edmund Bjork

The economy of Ukraine that aimed at active integration into the world economy, the tourism industry is becoming a determinant of social-economic development, but the pace of change remains unsatisfactory, as it is evidenced the lowest position in the world rankings tourist market. Based on the analysis of the dynamics of statistics: the share of tourism in GDP, and generated direct employment, tourism investments in capital, the volume of budget financing of tourism the role and place of tourism in the national economy are investigated. The state's role in the organization and development of tourism in different countries is given and singled out three types of models of state regulation of this important component of the national economy. The basic directions of reforming the system of state regulation of Ukraine's tourist industry - institutional, legal and strategic support are showed. Ways of improvement of the current governance model of tourism in Ukraine are singled out.

Key words: tourism; national economy; state management of tourism; state regulation of tourism; tourism reform.

Formulation of the problem. Tourism is an effective and promising sector of the economy of many countries. It helps to diversify the economy, stimulate investment, accelerating the development of export potential, involvement in international activities related industries, also plays an important role in creating new jobs, providing employment, increasing incomes and improving the welfare of the nation. The influence of tourism on economic development is also reveals in increasing of business activity, magnification of production amount and realization of goods and services due to the growth of payable demand.

In economic of Ukraine, aimed at active integration into the world economy, the tourism industry is becoming a determinant of social and economic development, but the pace of change remains unsatisfactory, which evidenced in the lowest position in the world rankings tourist market. The improving of situation can be achieved by reforming the system of state regulation of the tourism industry in Ukraine.

Analysis of recent research and publications. Theoretical and practical aspects of the formation and functioning of state regulation of the tourism industry are reflected in scientific works of domestic and foreign scientists, namely L. Agafonova [2], M. Byrzhakov [4], A.

(C) Iryna Zhuk, 2016 
Boyko [3], V. Vahmystrov [9], V. Zaytseva [12], M. Malska [6], P. Putsenteylo [7], T. Tkachenko [8], V. Fedorchenko [5] and others.

Separation of still unsolved parts of the problem. Despite the intensification of research efforts aimed on the analysis of tourism, some aspects of state regulation of the industry are not theoretically meaningful. There are also not enough scientifically based practical recommendations about state regulation of the tourism industry at the national, regional and local levels, taking into account the political and socio-economic transformation processes taking place in Ukraine. Formation of strategy of development of the tourism industry and create conditions for its effective implementation - important task today.

The purpose of research is being necessary in search of a new scientific approaches to reforming the tourism industry as a part of the socio-economic development of Ukraine.

Showing the main material research. State regulation of tourism development belongs to the mechanisms of implementation of the state policy in the sphere of tourism. The development of the tourism industry is characterized by positive dynamics of quantitative and qualitative indicators: increasing of the tourist flows, allocations to the state and local budgets, increasing of employment and more.

State regulation of the tourism industry - a set of forms and methods of influence of the authorities on the development of tourism sector and creating the conditions for effective cooperation between public authorities, local governments and the private sector on the development of tourism through different mechanisms: administrative, organizational, economic, legal, environmental etc.

The task of state regulation of the tourism industry are determined by the major trends of development of tourism in domestic and international markets of touristic services powered by the authorities and the state participation in the formation of the basic conditions for the functioning of tourism, its real possibilities.

It is well known that the tourism makes it possible for the state cheaply developing a small and the medium businesses, to create new jobs, attract investments, developing infrastructure. Modern tourism industry is considered as a separate type of economic activity and as an interdisciplinary complex.

According to the rates of a World Tourism Organization, currently tourism ranks the first place among industries of world economic complex of export of goods and services. Producing $9 \%$ of global national product, attracting $7 \%$ of global investments, tourism is now the most powerful sphere of the world economy. Tourism accounts $11 \%$ of consumer spendings, $5 \%$ of tax revenues. For the currency incomings, growing annually by $10 \%$, tourism is ahead of exports petroleum products, telecommunications equipment, engineering [10].

Ukraine has a good objective conditions for entering into the most developed touristic countries of the world. However, despite the high potential tourist and recreational resources, our country is not even included in the ranking table, which includes 75 countries that have the highest income from tourism, because the share of tourism in the economy is very low.

The basis of the analysis of the role and place of tourism in the economy of Ukraine is studying the dynamics of statistic indexes: of the share of tourism in GDP, levels of direct and generated employment, amount of capital touristic investments, amount of budget 
financing of tourism (see table.). In Ukraine tourism forms less than $1 \%$ of total GDP (in Europe $-10 \%$ ), the share of export of travel services in the structure of export of goods and services in Ukraine is $0,7 \%$ (in Europe - $30 \%$ ).

Statistical indicators of the impact of tourism on the economy of Ukraine

\begin{tabular}{|l|c|c|c|}
\hline \multicolumn{1}{|c|}{ Indicator } & \multicolumn{3}{c|}{ Years } \\
\cline { 2 - 4 } & $\mathbf{2 0 1 4}$ & $\mathbf{2 0 1 5}$ & $\mathbf{2 0 2 5}$ \\
\hline The direct contribution of tourism into GDP, billion UAH & 28,4 & 28,1 & 42,0 \\
\hline The total contribution of tourism into GDP, billion UAH & 106,7 & 104,3 & 151,2 \\
\hline Direct employment in tourism, thsd. of people & 333 & 342 & 322 \\
\hline Total employment in tourism, millions of people & 1,27 & 1,29 & 1,16 \\
\hline
\end{tabular}

Note: compiled by the author according to the World Council of Travel and Tourism [11]

According to the World Council of Travel and Tourism, the direct contribution of tourism into GDP in 2014 was 28,4 billion USD (1,9\% of GDP). In 2015 it was 28,1 billion USD, decreased on 1\%. According to the forecasts of the World Council of Travel and Tourism, to the 2025 direct contribution of tourism to GDP will be increased on $4,1 \%$ annually, to 42 billion (1,8 \% of GDP).

The total contribution of tourism into GDP in 2014 reached 106,7 billion USD (7,1\% of GDP) and in 2015 was 104,3 billion UAH (7,2 \% of GDP). According to the forecasts, by 2025 this indicator will be increased to $3,8 \%$ and will be 151,2 billion USD $(6,5 \%$ of GDP).

The direct employment in tourism in 2014 was 333 thsd. people (1,7 \% of all workers) in 2015 it was increased by $2,8 \%$ to 342 thsd. people (1,7\% of all employees). By 2025 this indicator will be 322 thsd. people, because of the predicted annual reduction of employment in tourism by $0,6 \%$ over the next ten years.

Overall tourism in 2014 was employed 1,27 million people (6,4 \% of all workers), in 2015 this indicator was increased to 1,29 million people, or $1,3 \%$ (6,5\% of employees). According to forecasts of the World Council of Travel and Tourism, by 2025 this indicator will reach 1,16 million people, or $1 \%$ decrease ( $6 \%$ of total employment).

As the research shows these indicators are much more lower than the corresponding indicators of the other countries of Central and Eastern Europe.

For Ukraine is typical an instability of Institute of Management, frequent changes of approaches to management of touristic sphere, unsatisfied scientific support development of tourism, extremely low level of realization its potential. For the last 15 years instead of reforming the touristic sphere by the government, six times was reformed the central department in the tourism industry, and its name. Characteristically, that each time with changing of the name, was approved the liquidation committee, which was doing a liquidation of a previous department and transferring of the cases and functions to the new department.

Because of reorganization (liquidation) of the State Agency of Tourism and Resorts, Ukraine has not completed its obligations mentioned in the Memorandum about rapport between the State Agency of Tourism and Resorts of Ukraine and the National Tourism 
Administration of China about assistance for group trips of chinese tourists to Ukraine, signed in Beijing on 5th of December, in 2013. As a result, the chinese tourists, each one of them is spending abroad more than 1000 USD, only to purchase souvenirs, are lost to Ukraine for a years

Ukrainian travel legislation is imperfect. Considering foreign policy vector, tourism should be used as a platform for testing a European standards and principles of work. Norms of the law "About Tourism" is necessary to align with EU directives in touristic sector, especially with the EU directive from 13.06.1990 № 90/314 EC about complex tourism, recreation and tours. The law must be more applied but not declarative should outline the basic requirements and mechanisms of implementation of services by the touristic companies, to stimulate the development of major for the state domestic and inbound tourism and activities of national tour operators engaged in export of touristic services.

In the process of reforming the system of state regulation of tourist industry of Ukraine appeared some problems which are requiring an urgent solutions: institutional, legislative and strategic (fig. 1). First of all is a discrepancy of existing regulatory basis to needs and trends of development of tourism industry, its inconsistency with international standards. In addition, the primary task is to create the structure of state regulation of tourism in Ukraine considering the current realities and experience of countries with a highly developed tourism industry.

Especially, tourism business needs a regulatory, methodical, organizational and informational support of government. Tourism can be an important factor in the socioeconomic and cultural development, contributing to an increase of employment, the development of urban infrastructure, reconstruction and preservation of memorials etc.
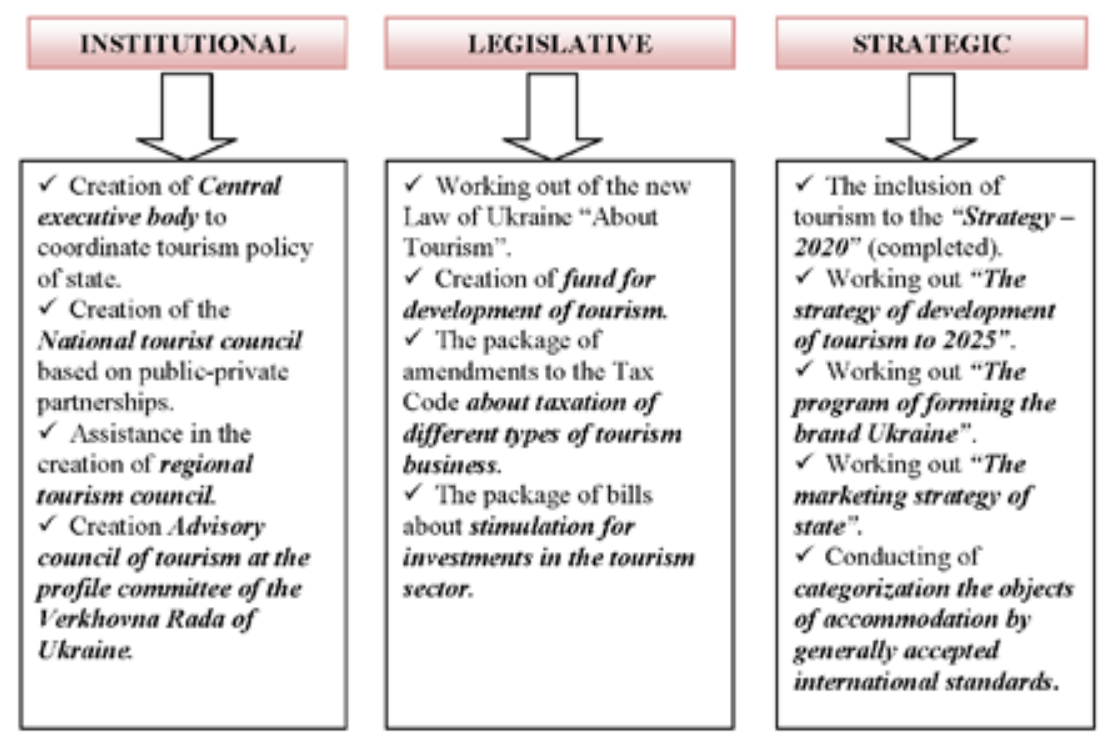

Fig. 1. The main components of tourism reform in Ukraine

Note: compiled by the author 
The most important problems of public administration in tourism include:

- liquidation of the State Agency for Tourism and Resorts;

- inefficiency of management and managers in the national tourism sector;

- imperfect and outdated regulatory basis (disparity to the current requirements to the Law of Ukraine "About Tourism", imperfect positions of the Tax Code);

- absence of the complex approach to the development of the industry - a complex development strategy, marketing strategy of the state;

- inefficiency of mechanisms attracting the investments in the sector.

On the basis of the state's role in the organization and development of tourism in different countries singled out three types of models of state regulation of this important component of the national economy.

In the first model, creation of central State Tourism Administration is not required, all issues are local solved by the principles of the market "selforganization". This model is used when tourism is not very important to the national economy or when the subjects of the tourist market are able to solve their problems successfully, without government participation, that hold a strong position. The similar model the management of tourism industry was established in the United States, after the liquidation of the state structure U.S. Travel and Tourism Administration (USTTA) in 1997, which was responsible for the development of tourism in the country.

The second model provides a strong and authoritative central body - the Ministry, which supervises the activities of all companies of the tourism industry in the country. For its realization required an appropriate conditions: significant investment in the tourism industry, particularly in advertising and marketing activities; investment in tourism infrastructure and others. Similar model of organization the management of tourism industry in Egypt, Mexico, Tunisia, Turkey and some other countries, where tourism serves as a major source of foreign exchange to the budget.

The third model prevailing in developed European countries. In countries where this model is used, the development of tourism solved in the "bowels" of diversified ministry at the relevant branch unit. Moreover, the unit of the Ministry responsible for tourism development in the country, operates in two directions: solve or regulate general issues of government regulation (the development of the regulatory, coordination of regional representative and executive bodies, international cooperation at the international level, collection and processing of statistical data and oth.) and directs, coordinates marketing activities (participation in exhibitions and international associations in the tourism sector, tourism management missions of the country abroad etc.).

This model of state regulation development of tourism conditionally named the "European". It has to be considered more detailed. A special actuality to this model gives a global transformation in the modern world. Ukraine needs a European vector of development and build a democratic, open civil society.

In developed European countries Central State Tourism Administration is working closely with local authorities and private business. This scheme of work was quite productive in terms of making constructive forms of cooperation and collaboration of administrative bodies at various levels of state and regional management, and to attract finances of private sector to implement the relevant government tasks. The consequence 
of this policy was the appearance in the regulation of tourism business a mixed ownership (public-private) institutions.

The first stages towards improving the current model of state administration in the field of tourism in Ukraine should be the creation of the National Tourism Board, specialized central executive council (independent or as part of the Ministry of Economic Development and Trade of Ukraine), which will deal with the formation and implementation of tourism development strategy and state policy in the field of tourism, and the Expert Council for tourism under the Verkhovna Rada of Ukraine (fig. 2).

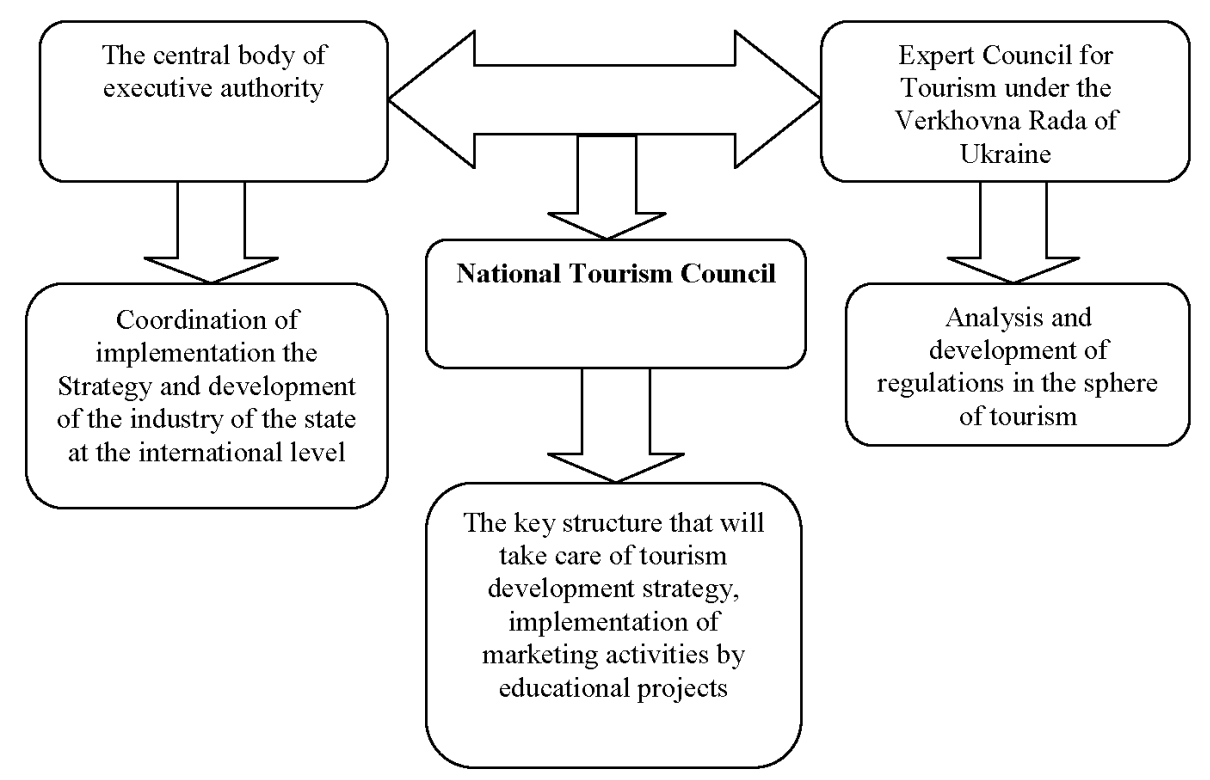

Fig. 2. The model of state administration in tourism

Note: compiled by the author

The overriding objective should be to develop an integrated tourism development strategy at national and regional levels, that will consider the experience of foreign countries, creating competitive in the international market national tourist product and a network of tourist offices abroad for the effective promotion of the product, the creation of national tourist multilingual Internet portal, marketing and advertising and information activities, harmonization of the regulatory basis of the tourism industry to international standards.

One of the priority strategy the development of Ukraine should be the development of inbound and domestic tourism capable significantly affect the employment, entrepreneurial activity, investment, and improve the image of the country. In countries that are leaders in the tourism sphere, has accumulated considerable experience with various power tools motivation of tourism activities. In Ukraine, where the state regulation of tourism was limited by development of strategies, development programs and more, important, 
using the experience of its neighbours, to implement a modern mechanisms of interaction between government and business, after determining recreational-tourism sector a priority strategy development, create incentives for small and medium business in the sphere of tourism; motivate the citizens of foreign countries to visit Ukraine.

In sum the main tasks of touristic reforms in Ukraine are:

Legally recognize the development of inbound and domestic tourism one of the priority strategic directions of economic development of country.

Legally to provide a real preferences for entrepreneurs.

Increasing of expenditure on popularizing the tourist resources of Ukraine at regional, national and international levels, provision the activity of tourist information centers.

The implementation into national legislation the European standards and European reports of the analysis of tourist flows.

Expanding the list of countries, whose citizens can enter to Ukraine without visas, extension of the duration of a single visit to Ukraine from 90 to 360 days.

Increasing of the state order for training the specialists of recreation and tourism in universities.

Creating a central executive body for regulation of inbound and domestic tourism in Ukraine and strengthen the competitiveness of domestic resorts.

Development and adoption of the new Law of Ukraine "About Tourism" on the principles of the priority of development an inbound and domestic tourism, public-private partnerships.

Conclusions and recommendations for further research. The process of decentralization, deregulation taking place in Ukraine, actualizes the problem of creating an integrated system of the state management the tourism industry that accords a modern requirements of dynamic development and implemented at various levels - national, regional, individual enterprise.

For successful reform is essential to enlist the support of tourist community, and this requires its broad public discussion, objective coverage of tourism industry in the media.

\section{REFERENCES}

1. About approval of the Concept of the State program of development a tourism and resorts for the period till 2022 : by the order of the Ministers Cabinet of Ukraine from 01.08.2013. - №638 [Electronic recourse]. - Mode of access : http://zakon4.rada.gov.ua/laws/show/638-2013-p

2. Agafonova L. G. Tourism, hotel and restaurant business: pricing, competition, government regulation : study guide / L. G. Agafonova, O. E. Agafonova. - Kyiv : Knowledge of Ukraine, 2002. - 358 p.

3. Boyko $O$. V. Features of the formation and implementation of the tourism policy: international, national, regional experience : monograph / O. V. Boyko ; red. A. U. Parfinenko. - Harkiv : HNU named V. N. Karazin, 2013. -279 p.

4. Byrzhakov M. B. Intro in tourism: Trips. Tourism and tourism industry. Legislation about tourism / M. B. Byrzhakov. - 3-ed edition. - SPb. : Publ. house "Gerda", 2002. - 320 p.

5. Legal regulation of touristic activity in Ukraine : digest of normative acts / red. V. K. Fedorchenko. Kyiv : Urinkom Inter, 2002. -640 p.

6. Malska M. P. Spatial systems of services (theory, methodology, practice) : monograph / M. P. Malska. - 
Kyiv : Knowledge, 2009. -363 p.

7. Putsenteylo P. R. Economics and organization of tourism and hotel business : study guide / P. R. Putsenteylo. - Kyiv : Center of educational literature, 2007. $-344 \mathrm{p}$.

8. Tkachenko T. I. Sustainable tourism development: theory, methodology, business realities : monograph / T. I. Tkachenko. - 2-nd edition, cor. and exp. - Kyiv, 2009. - 463 p.

9. Vachmystrov V. P. Legal provision of tourism : study guide / V. P. Vachmystrov, S. I. Vachmystrov. SPb. : Publ. Mychaylov V. A., 2005. - 288 p.

10. World Tourism Organization UNWTO [Electronic recourse]. - Mode of access : http://www2. unwto.org/

11. World Travel \& Tourism Council (WTTC) [Electronic recourse]. - Mode of access : https://www. wttc.org/

12. Zaytseva V. M. Legal regulation of tourism activity : study guide / V. M. Zaytseva, U. V. Filey. Zaporizhya : Prosvita, 2010. -220 p.

Стаття надійшла до редколегії 12.10.2016

Прийнята до друку 18.10.2016

\title{
РЕФОРМУВАННЯ СФЕРИ ТУРИЗМУ В УКРАЇНІ
}

\author{
Ірина Жук \\ Львівський національний університет імені Івана Франка, \\ вул. Університетська, 1, м. Львів, Украӥна, 79000, \\ E-mail: zhukiryna0312@gmail.com
}

В економіці України, що спрямована на активну інтеграцію у світове господарство, туристична галузь поступово перетворюється на детермінанту соціально-економічного розвитку. Однак темпи цих перетворень залишаються незадовільними, про що свідчать найнижчі позиції у світових рейтингах туристичного ринку. На основі аналізу динаміки статистичних показників - частки туризму у ВВП, прямої та генерованої зайнятості, обсягів капітальних туристичних інвестицій, обсягів бюджетного фінансування туризму - досліджено роль і місце туризму в національній економіці. 3 урахуванням ролі держави в організації та розвитку туристичної діяльності в різних країнах світу виокремлено три типи моделей державного регулювання цієї важливої складової національної економіки. Висвітлено основні напрями реформування системи державного регулювання туристичної галузі України, його інституційного, законодавчого та стратегічного забезпечення. Окреслено шляхи удосконалення чинної моделі державного управління галузі туризму в Україні.

Ключові слова: туризм; національна економіка; державне управління туризмом; державне регулювання туризму; туристична реформа. 